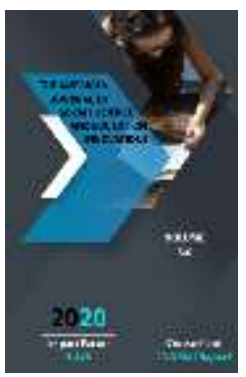

\title{
History Of Handicrafts Of Kashkadarya Oasis In The XIX- Early XX Centuries
}

\author{
Akhmadjon Kholikulov \\ National University of Uzbekistan, Department of History of Uzbekistan Associate Professor, \\ Candidate of Historical Sciences, Uzbekistan
}

Journal Website: http://usajournalshub.c om/index,php/tajssei

Copyright: Original content from this work may be used under the terms of the creative commons attributes 4.0 licence.

\section{ABSTRACT}

It is known that various crafts have been developed in Central Asia since ancient times. In particular, in the Kashkadarya oasis a number of branches of handicrafts have developed. This article provides information on the history of handicrafts in the Kashkadarya oasis.

\section{KEYWORDS}

Karshi, Guzar, textile, pottery, jewelry, blacksmithing, carpentry, tannery.

\section{INTRODUCTION}

History of handicrafts of Kashkadarya oasis O.A. Sukhareva, S.B. Lunina, M.K. reflected in a number of articles and works by scholars. In this article, we will briefly classify the types of oasis crafts of the period under study and focus on an analysis of some of the lesser-known features of handicrafts based on the sources.
It is known that in the early XIX-XX centuries Karshi and Shakhrisabz were the largest trade cities, while the city of Kitab was a leading center of carpentry and handicrafts in general. During this period, some types of trade and handicrafts were also developed in Guzar, Yakkabog and Chirakchi. 


\section{THE MAIN RESULTS AND FINDINGS}

In the period under consideration, handicrafts were one of the leading sectors of the oasis economy, and its textile, pottery, jewelry, blacksmithing, carpentry, tannery-related types, and other industries existed. These types of handicrafts are more developed in Karshi, Shakhrisabz and Kitab.

As in the whole Middle Ages, in the XIX-early XX centuries the leading branch of handicrafts was textiles. Types of textiles such as yarn spinning, fabric weaving and the production of ready-made garments have become a tradition. The raw materials needed for these industries: wool, cotton and silk are grown in the oasis itself. Spinning wool is considered to be the oldest occupation in textiles. Wool yarn production is widely developed in traditional livestock centers, steppe and foothill villages. The production of cotton yarn is well established on irrigated lands.

Among the fabrics produced in the cities of the oasis, the weight of ice was high. This simple, crisp and warm fabric is made from cotton yarn. It was prepared by many in Shahrisabz and Karshi. According to Mahmud ibn Wali, a large quantity of sarbas-boz (unpainted white cloth) was made in Shahrisabz. Recent literature also mentions that guzars specializing in making ice have been preserved in Shakhrisabz. The ice is used to make clothes, turbans, tablecloths, etc., worn by the majority of the population. The gray is painted in different colors and a new fabric is created by pressing a pattern on it. It is used to make women's clothes, bedding and more. According to O.A. Sukhareva, the Chitgars from Shahrisabz lived in the guzar of the Chairman of the city. Fabric masters also lived in a separate guzar.
Among the fabrics made in the cities of the oasis, the fabric called "olacha" was the most popular. Olacha is a simple fabric woven from cotton and silk, decorated with frames of different colors. Its varieties are woven like zibak, silk alacha, farangi. Farangi olacha is woven from imported yarn. Olacha is also produced in large quantities in Shakhrisabz, but the main center for making olacha is Karshi. According to N.Khanykov, the preparation of oysters plays an important role in the activities of the population of this city. The masters who made Olacha lived in the city's Upper Zagza guzar. Gowns, coats and other outerwear are mainly made of this fabric. In the early twentieth century, the masters of Karshi were so famous for making alacha that there were no equivalent masters in the whole khanate. This can be seen in the activities of Mulla Axun, who lived in Karshi in the middle of the 19th century and was known as Axun olacha. Mullo Axun's workshop employed more than 40 craftsmen, as well as more than 20 of his masters in neighboring villages. Overall, the Mulla Axun workshop was the largest weaving workshop in Central Asia.

Silk fabrics are also well developed in the cities of the oasis, especially in Shakhrisabz and Karshi. In the cities of the oasis lived readymade clothes, including hats. Among the hats, Shahrisabz skullcaps were the most popular. Karshi's Makhsumabad neighbourhood was the leader in weaving adras. According to L.Sobolev, during the reign of Amir Shah Murad, adras weavers brought from Merv helped not only residents of Bukhara, Samarkand and Urgut, but also artisans of Karshi to master adras weaving.

Another leading branch of the craft in the period under consideration was pottery. 
During this period, a unique artistic style emerged in the pottery of the oasis. The cities of Karshi, Shakhrisabz and Kitab are the main centers of pottery. In these cities, potters lived in separate guzars.

According to M.K. Rakhimov, Central Asian ceramics is divided into two main types: Kosagar pottery and Kuzagar pottery. Different sizes of plates, bowls and other products made by Kosagar masters were in great demand among the population of the oasis. These dishes are decorated and glazed with various patterns, and in the patterns, along with elements typical of the whole of Central Asia, patterns with a local character are also common.

The masters of the oasis made jugs, palms, various dishes, sunscreens, jars and other products (tandoor, baked bricks, etc.) of different sizes and shapes. The oasis potters were able to fully meet the local need. This indicates that pottery is much more developed in the oasis.

Among the types of handicrafts of this period, the production of metal products was also of great importance. Metal craftsmen lived in Karshi and Shakhrisabz. They are divided into specialties such as blacksmith and coppersmith. Blacksmiths made a variety of tools used in agriculture and everyday life - hoe, waist, sickle, ax, knife, nail, needle and other small metal tools. The blacksmiths of Karshi lived in the guzars of Temirchi, Chilangar and Harrotlik of the city, and the blacksmiths and carpenters of Shahrisabz lived in the guzar of Pottery. That is why a part of the Pottery guzar is also called Charkhchilik. Their workshops were also in those places. Nineteenth-century tourists praised some of the masterpieces of resistance.
Coppersmiths also lived mainly in Karshi and Shakhrisabz. The coppersmiths of Karshi lived in the guzar in front of the coppersmith's gate, and the masters of Shahrisabz lived in the guzar of the pool. The copperware of the Karshi and Shahrisabz masters was very similar in shape and differed greatly from that of the Khiva and Bukhara masters.

Karshi was the largest center of the Bukhara Khanate for the production of silver and copperware. The items made by resistance masters were popular all over Central Asia. The demand for copper jugs in Karshi was especially high. Also here, a large number of copper items decorated with artificial blue and red rubies were produced.

Degree masters also lived in the cities. They made various agricultural products, cast iron pots, lamps and other items by casting them in special molds. Degrezi masters from Shakhrisabz lived in Degrezi and Juyi-Heytak guzars of the city. Degrezi masters also worked in Karshi and Kitab.

There were also masters of making weapons in the cities of the oasis. For example, in the XIX century in Kitab and Shakhrisabz balls were made with the help of Afghan and Persian specialists.

Jewelry also flourished in the cities during this period. Jewelers made precious stones and metals, various jewelry and other items from glass. Their products were in great demand among the wealthy. Jewelry is developed in Shahrisabz, Kitab and Karshi. In the 19th century, Karshi, Shakhrisabz and Kitab were among the leading jewelry centers in Central Asia, such as Bukhara, Khiva, Samarkand, Tashkent and Kokand. 
Tanning is also developed in the cities of the oasis. From the leathers processed by the leatherworkers, the shoemakers made various shoes, telpak, fur, meshes for water and kumiz, various bags, and other household items. The masters of leather from Shakhrisabz lived in three guzars of the city (Big and Small Charmgar, Meshgar), and the masters from Karshi and Kitab lived in the guzar of Charmgars of their cities. Analysis of statistical data for the end of the XIX century shows that in the city of Karshi there were 5 enterprises processing sheepskin for sewing.

One of the largest centers for the production of leather goods in the oasis is the city of Karshi. The products produced by the resistance tanners not only met the demand of the domestic market, but also were exported in large quantities to neighboring provinces and abroad.

Among the types of handicrafts, carpentry also played an important role. The carpenters made various agricultural utensils, doors, cradles, tables, bowls, spoons, carts, and other utensils. Wood carving is also well developed in the oasis.

In the city of Karshi, an entire street population is engaged in oil production, where flaxseed oil is extracted from several existing mills. Tens of thousands of pounds of flax imported from Denau, Gissar, Kofirnihon, Baljuvon and Kulob principalities were processed in one day.

Karshi was also famous for its confectionery. It produces sweets in the form of apricots, peaches, pears, apples, quinces and figs from a mixture of sugar and sheep oil.

Not far from the city center lived the famous Karshi confectioners of the entire Bukhara emirate. They made sweets similar in shape and color to pears, apples, apricots, figs, and other fruits from a dough mixed with sugar, butter, nuts, and pistachios. Among confectionery products the following are considered to be in demand: pahlava: made of a mixture of sugar, butter and almond dough in saffron color, cut into rectangles; confectionery: a round dough made of flour and sugar with pistachios and almond kernels in it; brine; several types of halva made with the addition of walnuts, almonds and sesame seeds; thirsty drinks.

In the territory of the Karshi principality there are deposits rich in fertilizers (saltpeter), and the local population was engaged in the extraction of fertilizers. The Persians of Baku were its main buyers.

Residents of separate villages in Shahrisabz and Karshi principalities were engaged in shawl weaving. The main part of the population of Guzar principality was made up of gray producers. Even the inhabitants of the Beklik region, where no cotton is grown, produced gray by substituting cotton for livestock products or dried fruits. Gray weaving is mainly done by women, and the inhabitants of three villages inhabited only by Tajiks: Eskibog, Butek and Chunagar, are engaged in the production of special gray. The gray was mainly produced for domestic needs and was not exported to other parts of the emirate.

Half the inhabitants of the village of Eskibog were engaged in the manufacture of iron utensils necessary for household needs. While these ironware was not as well-known in the emirate as Qorategin knives, it did well for domestic use. In the Guzar principality, Eskibog is the only iron-producing village, and for the residents of other large villages, blacksmithing was the main occupation. 
About 1,500 people in the Guzar principality were engaged in coal mining, while the main occupation of the residents of Abullays and Qayirma villages was camel transportation. In addition, several hundred people were engaged in the extraction of salt and its transportation to Samarkand.

The Jews living in Guzar were engaged not only in trade, but also in handicrafts. No equivalent was found in the city to dye the fabric and bake the bread.

Among the types of handicrafts in the oasis, milling is also widespread. Special masters were engaged in this field. For example, there are 40 water mills in Karshi, 20 in Guzar, about 30 in Chirakchi, 40 in Yakkabog, 120 in Shakhrisabz, and 70 in Kitab, which have always met the needs of the population. According to another statistic, 540 flour mills and 190 rice mills are operating in Kitab, Shahrisabz and Yakkabag principalities, 30 flour mills and 10 rice mills in Chirakchi principality, 40 flour mills and 15 rice mills in Guzar principality.

In the Karshi principality, local artisans also make products for daily needs, such as soap and candles. Goat fat was used in the preparation of these products.

\section{CONCLUSION}

It should be noted that the products produced by the craftsmen of the oasis almost met the needs of the local population. Some of the products have been removed. The role of local traders was important in this work.

During the period under study, the cities of the oasis played an important role as important centers of handicrafts and trade. Among them, especially the cities of Karshi and Shakhrisabz stood out. These cities played an important role not only in the economy of the oasis, but in the whole emirate.

\section{REFERENCES}

1. Mahmoud ibn Wali. Bahr al-asror. Geography / Per. B. Akhmedov. Tashkent: Fan, 1985 . P. 176.

2. Sukhareva O. A. On the history of the cities of the Bukhara Khanate. Tashkent, 1958 . P. 138.

3. Mukminova R.G. Essays on the history of craft in Samarkand and Bukhara in the 16 th century. - T., 1976 . P. 66.

4. Sukhareva O. A. On the history of cities ... P. 138.

5. Grebenkin A. Crafts activities of the Tajiks of the Zarafshan district // Turkestan collection. - T. 52 . P. 511.

6. Khanykov N. Description of the Bukhara Khanate. - SPb., 1843 .-- P. 109.

7. Sukhareva O.A. On the history of cities ... - p. 124.

8. Sobolev L. Recent history of the Bukhara and Kokand khanates // Turkestanskoe vedomosti. 1876. - No. 26.

9. Sukhareva O. A. To the history of cities ... - pp. 125, 137 .; Krasheninnikova N.I. Kitab's past ... - p. 32.; Hamidova M.S. From the history of pottery of Shakhrisabz oasis in the XVIII-early XIX centuries // Echoes from Maziy. Tashkent, 2008. -№ 4 (40). Pp. 11-13.

10. Raximov M.K. Artistic ceramics of Uzbekistan. - Tashkent: AN UzSSR, 1961. P. 13.

11. Statistical materials on Asia. - SPb .: Voennaya tipografiya, 1886. - Vyp. XXI. S. 33 . 
12. Tanieva G. Excerpts from the history of the Karshi principality. - Toshkent, 2006. - Б. 32-33.

13. Geyer I.I. Turkestan. - Tashkent, 1909. C. 209.

14. Semyonov-Tyan-Shanskiy V.P. Russia: full geographical description. - T. XIX. Turkestanskiy kray. - SPb .: Izd-vo A.F.Devriena, 1913. P. 663.

15. Geyer I.I. That work ... P. 197.

16. Kholikulov, A. B. (2019). Bukhara emirate's farming in the XIX-XX centuries (in the case of Kashkadarya oasis stables). ISJ Theoretical \& Applied Science, 04 (72), 546-549.

17. Ochildiev F.B Social Relationship And Tax Types In The XIX - XX Century In Bukhara Emirate INTERNATIONAL JOURNAL OF SCIENTIFIC \& TECHNOLOGY RESEARCH VOLUME 9, ISSUE 01, JANUARY 2020 ISSN 2277-8616

18. Rasuljanovna, I. N., \& Rakhmonqulovich, K. N. (2020). Trade Relations Between Ancient Bacteria And China On The II-I BC. The American Journal of Social Science and Education Innovations, 2(07), 47-51.

19. Karimov, N. R. (2020). A True Successor of Great Central Asian Scholars. Journal «Bulletin Social-Economic and Humanitarian Research,(7), 62-69. 